\title{
PERLINDUNGAN DATA PRIBADI \\ SEBAGAI BAGIAN DARI HAK ASASI MANUSIA \\ ATAS PERLINDUNGAN DIRI PRIBADI \\ Suatu Tinjauan Komparatif Dengan Peraturan Perundang-Undangan \\ Di Negara Lain
}

Hanifan Niffari

Magister Ilmu Hukum Fakultas Hukum Universitas Indonesia

hanifanniffari89@gmail.com

\begin{abstract}
Abstrak
Perlindungan data pribadi sebagai bagian dari perlindungan diri pribadi yang diamanatkan dalam Pasal 28G ayat (1) Undang-Undang Dasar Negara Republik Indonesia Tahun 1945 hingga saat ini belum diatur secara terintegrasi dalam undangundang tersendiri. Perlunya pengaturan perlindungan data pribadi dalam undang-undang tersendiri sangat penting mengingat banyaknya penyalahgunaan data pribadi yang tidak sesuai dengan peruntukkan awalnya seperti jual beli data pribadi secara komersil. Pengaturan perlindungan data pribadi saat ini masih diatur secara terpisah di beberapa undang-undang yang tidak khusus mengatur perlindungan data pribadi. Penerapan perlindungan data pribadi perlu melihat pengaturan yang telah dilakukan di negaranegara lain untuk kemudian dilihat dan dikaji sesuai dengan konteks keadaan sosiologis di Indonesia. Tulisan ini membahas konsep umum perlindungan data pribadi dan membandingkan pengaturan-pengaturan perlindungan data pribadi di negara-negara lain serta memberikan analisa hasil perbandingan tersebut untuk kemudian ditelaah penerapannya di Indonesia.
\end{abstract}

Kata Kunci: Perlindungan Data Pribadi, Data Pribadi, undang-undang, perbandingan hukum

\begin{abstract}
Data privacy protection as a part of personal privacy protection stated in Article $28 G$ paragraph 1 The 1945 Constitution of Republic Indonesia has not been regulated so far in an integrated manner in a separate law. The urgency of data privacy regulation in a separate law is very important considering the number of personal data misused not in accordance with its initial purpose such as the transaction of personal data commercially. The regulation of data privacy is currently still regulated separately in several laws that do not specifically regulate the protection of personal data. The Implementation of personal data protection needs to look at the regulations that have been made in other countries to then be examined and studied in accordance with the context of the sociological situation in Indonesia. This research discusses the general concept of personal data protection and compares the personal data protection regulations in other countries and provides an analysis of the results of these comparisons for later application in Indonesia.
\end{abstract}

Key words: Personal Data Protection, Data Privacy, Laws, Regulation, Law Comparison 


\section{Pendahuluan}

Dalam Pasal 28G ayat (1) Undang-Undang Dasar Negara Republik Indonesia Tahun 1945 menyebutkan bahwa setiap orang berhak atas perlindungan diri pribadi, keluarga, kehormatan, martabat, dan harta benda yang di bawah kekuasaannya, serta berhak atas rasa aman dan perlindungan dari ancaman ketakutan untuk berbuat atau tidak berbuat sesuatu yang merupakan hak asasi manusia. Terkait hak pribadi sebagai hak asasi manusia dijelaskan Danrivanto Budhijanto, bahwa "Perlindungan terhadap hak-hak pribadi atau hak-hak privat akan meningkatkan nilai-nilai kemanusiaan, meningkatkan hubungan antara individu dan masyarakatnya, meningkatkan kemandirian atau otonomi untuk melakukan kontrol dan mendapatkan kepantasan, serta meningkatkan toleransi dan menjauhkan dari perlakuan diskriminasi serta membatasi kekuasaan pemerintah. ${ }^{1}$

Jika melihat uraian di atas maka perlindungan diri pribadi sebagaimana disebutkan dalam Pasal 28G ayat (1) Undang-Undang Dasar Negara Republik Indonesia Tahun 1945 di atas erat kaitannya dengan perlindungan terhadap hak-hak pribadi atau hak-hak privat. Dalam sejarah perkembangannya, privasi merupakan suatu konsep yang bersifat universal dan dikenal di berbagai negara baik tertulis dalam bentuk undangundang maupun tidak tertulis dalam bentuk aturan moral. ${ }^{2}$ Hak tersebut berkaitan dengan kebutuhan spiritual manusia yaitu kebutuhan untuk dihargai perasaan, pikiran dan hak untuk menikmati kehidupannya atau disebut dengan the right to be let alone. ${ }^{3}$

Konsep perlindungan data sering diperlakukan sebagai bagian dari perlindungan privasi. Perlindungan data pada dasarnya dapat berhubungan secara khusus dengan privasi seperti yang dikemukakan oleh Allan Westin yang untuk pertama kali mendefinisikan privasi sebagai hak individu, grup atau lembaga untuk menentukan

1 Danrivanto Budhijanto, Hukum Telekomunikasi, Penyiaran \& Teknologi Informasi: Regulasi \& Konvergensi, PT. Refika Aditama, Bandung, 2010, hlm. 4.

2 https://privacyinternational.org/, diakses pada tanggal 11 November 2018. Lihat juga Banisar, Privacy $\mathcal{E}$ Human Rights, An International Survey of Privacy Laws and Developments, Electronic Privacy Information Centre, Washington. D.C, 2000, hlm. 1-3. Seperti yang dikutip dalam Sinta Dewi Rosadi, Perlindungan Privasi atas Informasi Pribadi dalam E-Commerce menurut Hukum Internasional, Widya Padjadjaran, Bandung, 2009, hlm. 45.

${ }^{3}$ Samuel Warren \& Louis D. Brandeis, "The Right To Privacy", Harvard Law Review, Volume 4, 1890, hlm. 1. 
apakah informasi tentang mereka akan dikomunikasikan atau tidak kepada pihak lain sehingga definisi yang dikemukakan oleh Westin disebut dengan information privacy karena menyangkut informasi pribadi. ${ }^{4}$

Perlindungan data juga merupakan hak asasi manusia yang fundamental, sejumlah negara telah mengakui perlindungan data sebagai hak konstitusional atau dalam bentuk 'habeas data' yakni hak seseorang untuk mendapatkan pengamanan terhadap datanya dan untuk pembenaran ketika ditemukan kesalahan terhadap datanya. Albania, Armenia, Filipina, Timor Leste, Kolombia dan Argentina adalah negara-negara dengan perbedaan sejarah dan budaya yang telah mengakui peran dari perlindungan data yang dapat memfasilitasi proses demokrasi dan telah menjamin perlindungannya dalam konstitusi mereka. ${ }^{5}$

Pengumpulan dan penyebarluasan data pribadi merupakan pelanggaran terhadap privasi ${ }^{6}$ seseorang karena hak privasi mencakup hak menentukan memberikan atau tidak memberikan data pribadi. ${ }^{7}$ Data pribadi merupakan suatu aset atau komoditas bernilai ekonomi tinggi. ${ }^{8}$ Isu mengenai pentingnya perlindungan data pribadi mulai menguat seiring dengan meningkatnya jumlah pengguna telepon seluler dan internet. Sejumlah kasus yang mencuat, terutama yang memiliki keterkaitan dengan kebocoran data pribadi seseorang dan bermuara kepada aksi penipuan atau tindak kriminal pornografi, menguatkan wacana pentingnya pembuatan aturan hukum untuk melindungi data pribadi. $^{9}$

\footnotetext{
${ }^{4}$ Menurut Alan Westin: Privacy is the claim of individuals, group or institution to determine for themselves when, how, and to what extent information about them is communicated to others dalam, Allan Westin, Alan F. Westin, Privacy and Freedom, London, 1967, hlm. 7.

${ }_{5}^{5}$ Graham Greenleaf, 76 Global Data Protection Laws, Privacy Laws \& Business Special Report, September 2011.

${ }^{6}$ Kamus Besar Bahasa Indonesia memberikan pengertian privasi berarti kebebasan dan keleluasaan diri, Kamus Besar Bahasa Indonesia, Edisi 3, Departemen Pendidikan Nasional dan PT. Balai Pustaka, Jakarta 2001.

7 Human Rights Committee General Comment No. 16 (1988) on the right to respect of privacy, family, home and correspondence, and protection of honour and reputation (art. 17) seperti yang dikutip dalam Privacy International Report, 2013, hlm. 1-2.

8 Edmon Makarim, Kompilasi Hukum Telematika, PT. Raja Grafindo Perkasa, Jakarta 2003, hlm. 3. Lihat juga M. Arsyad Sanusi, Teknologi Informasi \& Hukum E-commerce, PT. Dian Ariesta, Jakarta, 2004, hlm. 9.

9 Wahyudi Djafar dan Asep Komarudin, Perlindungan Hak Atas Privasi di Internet-Beberapa Penjelasan Kunci, Elsam, Jakarta, 2014, hlm. 2
} 
Kasus yang banyak terjadi di Indonesia adalah jual beli data konsumen. Konsumen yang datanya berhasil diperoleh menjadi target pemasaran suatu produk perusahaan atau perseorangan. Tidak sedikit pula pengguna internet menawarkan jasa jual-beli akun atau pengikut. Padahal praktik tersebut membuka ruang terjadinya penyalahgunaan data seseorang untuk melakukan kejahatan. Kasus terbaru yaitu penipuan dan penggelapan kartu kredit nasabah dengan tersangka Imam Zahali (IZ), yang menyebabkan kerugikan pihak bank sekitar Rp 250 juta setelah menggunakan kartu kredit nasabah untuk transaksi gesek tunai. Hasil kejahatan itu kemudian digunakan untuk kepentingan dirinya, salah satunya menunaikan ibadah haji di Tanah Suci Mekah. Pelaku mendapatkan data nasabah dengan cara membelinya di internet sebesar Rp 800 ribu untuk 25 data. Dari data tersebut, pelaku kemudian menghubungi korban dengan mengaku sebagai sales kartu kredit dan menawarkan untuk menaikkan limit kartu kredit. ${ }^{10}$

Bentuk lain dari diabaikannya perlindungan terhadap privasi adalah munculnya sebuah pesan berisi iklan yang biasa disebut Location-Based Messaging. Pesan tersebut akan terkirim otomatis kepada seseorang jika ia berada di tempat tertentu. Padahal, belum tentu ia pernah menyetujui suatu perjanjian dengan sang provider dan memperbolehkan mereka merekam setiap aktivitasnya. ${ }^{11}$ Perusahaan seperti Google, Gojek, dan Grab tidak hanya menyediakan layanan bagi pengguna mereka. Namun, mereka juga mengumpulkan data pribadi penggunanya. Pengumpulan besar-besaran set data yang bisa dicari, dikumpulkan, dan direferensi silang ini dinamakan Big Data. Tidak hanya perusahaan, tetapi individu dan pemerintahan juga bisa mengumpulkan data pribadi. ${ }^{12}$

Indonesia belum memiliki peraturan perundang-undangan yang secara khusus mengatur mengenai perlindungan data pribadi. Berbagai macam permasalahan di atas

10 https://news.detik.com/berita/d-3158671/duh-sales-kartu-kredit-gadungan-ini-gunakan-uang-harambuat-naik-haji, diakses pada tanggal 11 November 2018 Pukul 23.05 WIB.

11 http://aitinesia.com/3-contoh-pelanggaran-privasi-yang-terjadi-di-internet diakses pada tanggal 11 November 2018 Pukul 23.05 WIB.

12 Indonesia sangat memerlukan undang-undang perlindungan data pribadi, http://theconversation.com/indonesia-sangat-memerlukan-undang-undang-perlindungan-data-pribadi92607, diakses pada tanggal 14 November 2018 Pukul 19.22 WIB. 
menuntut pemerintah Indonesia untuk melindungi masyarakat dan mengatur masalah perlindungan atas data pribadi dan menyiapkan berbagai bentuk perlindungan hukum. Selain itu, dalam Undang-Undang Nomor 17 Tahun 2007 tentang Rencana Pembangunan Jangka Panjang 2005-2025 juga telah ditentukan bahwa untuk mewujudkan bangsa yang berdaya saing harus meningkatkan pemanfaatan ilmu pengetahuan dan teknologi. Salah satunya melalui peraturan yang terkait dengan privasi. 13

\section{Rumusan Masalah}

1. Bagaimanakah konsep perlindungan data pribadi sebagai wujud dari hak asasi manusia perlindungan diri pribadi di Indonesia dan Negara lain?

2. Apakah penerapan hak atas perlindungan data pribadi di negara lain tersebut dapat diterapkan di Indonesia?

\section{Pembahasan}

\section{Konsep Perlindungan Data Pribadi Di Indonesia Dan Negara Lain}

Perlindungan hak-hak pribadi diatur dalam Undang-Undang Dasar Negara Republik Indonesia Tahun 1945 Pasal 28G ayat (1), yang menyatakan bahwa "Setiap orang berhak atas perlindungan diri pribadi, keluarga, kehormatan, martabat, dan harta benda yang di bawah kekuasaannya, serta berhak atas rasa aman dan perlindungan dari ancaman ketakutan untuk berbuat atau tidak berbuat sesuatu yang merupakan hak asasi."

Hak perlindungan data pribadi berkembang dari hak untuk menghormati kehidupan pribadi atau disebut the right to private life. Konsep kehidupan pribadi berhubungan dengan manusia sebagai makhluk hidup. Dengan demikian orang perorangan adalah pemilik utama dari hak perlindungan data pribadi. ${ }^{14}$ Suatu data

${ }^{13}$ Rencana Pembangunan Jangka Panjang Nasional 2005-2025, hlm. 108.

${ }^{14}$ European Union Agency for Fundamental Rights and Council of Europe, Supra no 5,. hal. 37. 
adalah data pribadi apabila data tersebut berhubungan dengan seseorang, sehingga dapat digunakan untuk mengidentifikasi orang tersebut, yaitu pemilik data. ${ }^{15}$

Penjelasan mengenai definisi data pribadi adalah hal penting untuk menjamin perlindungan data tersebut. Sejauh ini dalam beberapa instrumen internasional dan regional seperti dalam European Union Data Protection Directive, European Union Data Protection Convention, dan the OECD Guidelines yang dimaksud dengan "data pribadi" adalah semua data yang berhubungan dengan orang-perorangan yang teridentifikasi dan dapat diidentifikasi (information relating to an identified or identifiable natural person). ${ }^{16}$

Dalam konteks Indonesia, Dalam Putusan No.5/PUU-VIII/2011, MK juga menulis bahwa right to privacy merupakan bagian dari hak asasi manusia (derogable rights) dan cakupan dari right to privacy meliputi informasi atau right to information privacy, disebut juga data privacy (data protection). Peraturan delegasi dari UU ITE, PP No. 82 Tahun 2012 tentang Penyelenggara Sistem dan Transaksi Elektronik, memuat definisi data pribadi yaitu data perseorangan tertentu yang disimpan, dirawat, dijaga kebenaran serta dilindungi kerahasiaannya (Pasal 1 angka 27). ${ }^{17}$

Pengaturan terhadap perlindungan data pribadi di Indonesia saat ini sebenarnya telah diatur dengan berbagai peraturan perundang-undangan yakni Undang Undang Nomor 7 Tahun 1992 tentang Perbankan sebagaimana Telah Diubah dengan Undang-Undang Nomor 10 Tahun 1998 tentang Perbankan, Undang Undang Nomor 36 Tahun 1999 tentang Telekomunikasi, Undang-Undang Republik Indonesia Nomor 11 Tahun 2008 tentang Informasi dan Transaksi Elektronik, Undang-Undang Nomor 7 Tahun 1971 tentang Ketentuan-Ketentuan

\footnotetext{
15 European Union Agency for Fundamental Rights and Council of Europe, Handbook on European Data Protection Law, Belgium, 2014, hal. 36.

16 Mark F. Kightlinger, E. Jason Albert, and Daniel P. Cooper, Convention for the Protection of Individuals with Regard to Automatic Processing of Personal Data of 28 January 1981, dapat diakses di: http://conventions.coe.int/treaty/EN/Treaties/HTML/108.htm.

17 Daniar Spriyadi, Data Pribadi dan Dua Dasar Legalitas Pemanfaatannya https://www.hukumonline.com/berita/baca/lt59cb4b3feba88/data-pribadi-dan-dua-dasar-legalitaspemanfaatannya-oleh--daniar-supriyadi, diakses pada tanggal 14 November 2018 Pukul 17.53 WIB
} 
Pokok Kearsipan, Undang-Undang Nomor 8 Tahun 1997 tentang Dokumen Perusahaan, Undang-Undang Nomor 36 Tahun 2009 tentang Kesehatan, dan Undang-Undang Nomor 23 Tahun 2006 tentang Administrasi Kependudukan. ${ }^{18}$

Dapat dilihat bahwa pengaturannnya masih bersifat terpisah dan tidak spesifik, oleh karena itu pengaturan perlindungan data pribadi secara terintegrasi diperlukan guna menjamin hak privasi masyarakat Indonesia secara keseluruhan mengingat ASEAN Human Rights Declaration yang baru saja diadopsi negaranegara ASEAN juga secara jelas mengakui hak privasi atas data pribadi dalam Pasal 21. Dewasa ini, telah banyak negara yang undang-undangnya mengatur tentang perlindungan data, setidaknya terdapat lebih dari 120 negara yang memiliki hukum tentang perlindungan data. ${ }^{19}$

Hukum hak asasi internasional telah menyoroti privasi digital, mengambil konsep-konsep dalam berbagai deklarasi mengenai hak asasi manusia dan kebebasan individu. Pada Sidang Umum PBB 2013, negara-negara anggota menyepakati adanya hak untuk privasi. Negara-negara anggota diminta untuk transparan dan bertanggung jawab ketika mengumpulkan data pribadi. Negara tetangga Indonesia seperti Singapura dan Australia juga telah menetapkan peraturan perundang-undangan mengenai privasi. Australia menetapkan Privacy Act pada 1988, sementara Singapura menetapkan Personal Data Protection Act pada 2012. Uni Eropa memiliki General Data Protection Regulation (GDPR) yang akan menjalankan aturan perlindungan data pribadi pada Mei 2018. Prinsip-prinsip yang berlaku dalam EU GDPR juga terlihat dalam presentasi ahli teknologi dan hukum perlindungan data pribadi, Berend van der Eijk, beliau menjelaskan mengenai prinsip transparansi: bahwa warga memiliki hak untuk mengakses, mengubah, dan menghapus data pribadi mereka pada waktu tertentu dari data pelanggan perusahaan. Perusahaan juga diminta untuk transparan mengenai mengapa mereka mengumpulkan data dan bagaimana mereka akan menggunakannya. Perlindungan

\footnotetext{
${ }^{18}$ http://scdc.binus.ac.id/himslaw/2017/03/perlindungan-data-pribadi-berdasarkan-hukum-positifindonesia/, diakses pada tanggal 14 November 2018 pukul 19.23 WIB

${ }^{19}$ Graham Greenleaf, Ibid.,
} 
data personal yang ada dalam GDPR terkait masalah ras, etnis, politik, kesehatan, gender, dan seksualitas yang berlaku. ${ }^{20}$

\section{Penerapan Hak Atas Perlindungan Data Pribadi Di Negara Lain Tersebut Dapat Diterapkan Di Indonesia}

Sampai saat ini masih terjadi ketidakpastian perlindungan privasi dan data pribadi, karena Indonesia belum memiliki instrumen hukum yang responsif terhadap adanya kebutuhan masyarakat untuk memperoleh perlindungan yang lebih kuat. Instrumen hukum yang ada di era ekonomi digital. Suatu instrumen hukum perlindungan privasi dan data pribadi di era ekonomi digital setidaknya harus memenuhi 3 kriteria: (1) memiliki karakter internasional; dan (2) merupakan elemen perekat individu dan masyarakat ekonomi. Karakteristik Pertama, perlindungan privasi dan data pribadi harus juga ditunjang dengan pengaturanpengaturan yang sifatnya lintas batas negara. Aturan semacam ini diantaranya adalah aturan bahwa transfer privasi dan data pribadi ke luar wilayah negara harus memerlukan persetujuan khusus, dan hanya dapat dilakukan ke negara yang memiliki perlindungan privasi dan data pribadi setara. Karakteristik Kedua, dalam konteks Era Ekonomi Digital, perlindungan privasi dan data pribadi harus juga mencakup perlindungan hak personal. Dengan kata lain selain harus merupakan hak-hak negatif yang menuntut negara tidak melakukan sesuatu agar hak tersebut terpenuhi, juga harus merupakan hak-hak positif yang pemenuhan hak nya hanya bias dilakukan dengan peran aktif dari negara. Era Ekonomi digital dengan segala karakteristik khusus dan perkembangan pesatnya tidak bisa menuntut negara untuk hanya diam, namun melakukan sesuatu yang lebih. Karakteristik Ketiga, perlindungan privasi dan data pribadi dapat meningkatkan kepercayaan individu untuk berpartisipasi menjadi masyarakat Era Ekonomi digital. ${ }^{21}$

\footnotetext{
${ }^{20}$ Indonesia sangat memerlukan undang-undang perlindungan data pribadi, http://theconversation.com/indonesia-sangat-memerlukan-undang-undang-perlindungan-data-pribadi92607, diakses pada tanggal 14 November 2018 Pukul 19.22 WIB.

${ }^{21}$ Sinta Dewi Rosadi, Perlindungan Privasi dan Data Pribadi Dalam Era Ekonomi Digital di Indonesia, VeJ Volume 4 Nomor 1, 2018 (Bandung: Fakultas Hukum Universitas Padjadjaran, 2018) : hal. 108-109
} 
Melihat bagaimanakah bentuk pengaturan perlindungan data pribadi yang sesuai di, maka pelindungan data pribadi dapat diterapkan di Indonesia dalam hal ini menurut penulis melihat model pengaturan di baik di region Asia dan khususnya Uni Eropa (EU General Data Privacy Regulation) sebagai berikut:

\section{1) Prinsip}

Secara umum, pengaturan di Indonesia dapat melihat dari model pengaturan Personal Personal Data Privacy Ordinance of 1995 (PDPO) Hong Kong yang terdiri dari 6 (enam) prinsip:

a) Batasan Pengumpulan Data Pribadi

Pengumpulan data pribadi terbatas pada pengumpulan data pribadi secara sah untuk tujuan yang secara langsung berhubungan dengan fungsi dari pengumpul.

b) Penggunaan dan Pengungkapan Data Pribadi

Prinsip ini membatasi pengungkapan data pribadi hanya untuk atau secara langsung berhubungan dengan tujuan awal pengumpulan data pribadi tersebut, atau apabila subjek data menyatakan persetujuan.

c) Kewajiban Kualitas Data dan Pemberian Saran kepada Pihak Ketiga

Prinsip ini mewajibkan seluruh langkah yang mungkin diambil untuk menjamin akurasi data pribadi (dengan mempertimbangkan tujuan penggunaan dan setiap tujuan yang langsung berhubungan), dan untuk menghapus atau tidak menggunakan data yang tidak akurat

d) Penghapusan dan Pemusnahan Data Pribadi

Berdasarkan prinsip ini, data pribadi tidak boleh disimpan lebih lama dari jangka waktu yang diperlukan untuk pemenuhan tujuan (termasuk setiap tujuan yang langsung berhubungan) untuk tujuan tersebut data digunakan atau akan digunakan di masa depan

e) Kewajiban Keamanan Data

Berdasarkan prinsip ini, pengelola data pribadi wajib melakukan setiap langkah yang memungkinkan untuk melindungi data pribadi dari akses yang 
tidak disengaja, atau pemrosesan, penghapusan, penghilangan, dan penggunaan tidak sah (tanpa hak)

f) Keterbukaan mengenai praktik-praktik

"Data User" harus mengambil langkah-langkah untuk menjamin bahwa setiap orang (tidak hanya subjek data) dapat menentukan kebijakan dan praktik mengenai data pribadi, jenis data pribadi yang disimpan "Data User", dan tujuan utama penggunaannya.

Mengenai prinsip-prinsip ini juga dapat melihat model pengaturan dalam EU GDPR article 5 bahwa: (a). Data pribadi harus diproses sesuai hukum, adil, dan transparan, (b) Diperoleh sesuai dengan tujuan penggunaannya, jelas, spesifik kecuali untuk kepentingan public, science dan riset. (c) Reevan dan terbatas sesuai dengan tujuan penggunaannya. (d) Terjamin keakuratannya. (e) Dibatasi penyimpanannya, (f) Terjamin keamanan, integritas dan kerahasiaannya.

2) Adanya pembagian/klasifikasi data pribadi umum dan khusus

Pengaturan Objek data pribadi khusus berupa agama/keyakinan, data kesehatan, biometric, kehidupan seksual, pandangan politik, catatan kejahatan, data anak, data keuangan pribadi dapat melihat model pengaturan data pribadi sensitif yang diatur di Negara-negara Eropa khususnya UK berdasarkan UK Data Protection Act 1998.

Data Pribadi spesifik juga diatur di EU GDPR khususnya di Article 9 yang meliputi "racial or ethnic origin, political opinions, religious or philosophical beliefs, or trade union membership, and the processing of genetic data, biometric data for the purpose of uniquely identifying a natural person, data concerning health or data concerning a natural person's sex life or sexual orientation”.

3) Hak-Hak pemilik Data Pribadi

Pengaturan terhadap hak-hak pemilik Data pribadi dapat melihat model pengaturan EU GDPR khususnya Chapter III yakni hak subjek data untuk transparansi informasi dalam hal pemrosesan data pribadinya, hak mengakses informasi terhadap tujaun pengumpulan data pribadinya (kontrak, pengendalinya), hak untuk menghapus dan koreksi data pribadinya, hak untuk 
menolak pemrosesan data pribadinya, hak untuk membatasi pemrosesan data pribadinya.

4) Pengendali dan pemroses

Pengaturan terhadap Pengendali dan Pemroses dapat melihat model pengaturan EU GDPR khususnya Chapter IV mengenai tanggung jawab pengendali, siapakah pengendalinya, pemroses, tanggung jawab pemroses dalam keamanan data pribadi, bentuk dan mekanisme pemrosesan data pribadi.

5) Kode Etik dan sertifikasi

Pengaturan terhadap Kode Etik dan sertifikasi dapat melihat model pengaturan EU GDPR khususnya Article 40 mengenai kode etik terhadap pengendali dan pemroses data pribadi yang dibentuk oleh Pemeritah, selain itu Sertifikasi terhadap pengendali dan pemroses data pribadi oleh pemerintah atau lembaga pemerintahan tertentu.

6) Transfer data pribadi ke negara lain atau organisasi internasional Pengaturan terhadap Transfer data pribadi ke negara lain atau organisasi internasional dapat melihat model pengaturan EU GDPR khususnya Chapter V bahwa negara yang menerima transfer data pribadi harus memiliki standar pengaturan yang sama terhadap perlindungan data pribadi.

7) Otoritas pengawas yang Independen Pengaturan terhadap otoritas pengawas yang independen berupa komisi atau lembaga dapat melihat model pengaturan EU GDPR khususnya Chapter VI dimana otoritas tersebut bertanggung jawab untuk mengawasi pengaturan perlindungan data pribadi sesuai regulasi yang ditetapkan yang bersifat independen dari pengaruh eksternal yang juga dapat sebagai wadah untuk penyelesaian sengketa.

8) Ganti Rugi dan Pertanggung jawaban, sanksi

Pengaturan terhadap Ganti Rugi dan Pertanggung jawaban, sanksi dapat melihat model pengaturan EU GDPR khususnya Chapter VIII bahwa contohnya pemilik data pribadi dapat meminta ganti rugi kepada pengendali dan/atau pemroses jika 
data pribadinya disalah gunakan dan diproses tidak sesuai dengan tujuan atau terdapat pelanggaran.

\section{Simpulan}

1. Perlindungan hak-hak pribadi di Indonesia merupakan kewajiban konstitusi negara yang diatur dalam Undang-Undang Dasar Negara Republik Indonesia Tahun 1945 Pasal 28G ayat (1). Perlindungan data pribadi merupakan bagian dari perlindungan diri pribadi yang diatur dalam konstitusi. Perlindungan data pribadi penting diatur mengingat data pribadi merupakan asset strategis yang sering disalahgunakan sehingga melanggar integritas privasi individu seperti misalnya memperjualbelikan untuk tujuan komersil tanpa persetujuan dari pemilik data pribadi dan penyalahgunaan data kesehatan.

2. Dalam konteks model pengaturan perlindungan data pribadi di Indonesia, dapat diterapkan khususnya dengan melihat model pengaturan di Uni Eropa melalui EU General Data Protection Regulation (EU GDPR) yang meliputi ruang lingkup: (1) pengaturan prinsip, (2) adanya pembagian/klasifikasi data pribadi umum dan khusus, (3) Hak-Hak pemilik Data Pribadi, (4) Pengendali dan pemroses data pribadi, (5) Kode Etik dan sertifikasi, (6) Transfer data pribadi ke negara lain atau organisasi internasional, (7) Otoritas pengawas yang Independen, dan (8) Ganti Rugi dan Pertanggung jawaban, sanksi.

\section{Daftar Pustaka}

\section{Buku}

Danrivanto, Budhijanto, Hukum Telekomunikasi, Penyiaran \& Teknologi Informasi: Regulasi \& Konvergensi, PT. Refika Aditama, Bandung, 2010.

European Union Agency for Fundamental Rights and Council of Europe, Handbook on European Data Protection Law, Belgium, 2014

Komarudin , Wahyudi Djafar dan Asep, Perlindungan Hak Atas Privasi di InternetBeberapa Penjelasan Kunci, Elsam, Jakarta, 2014

Makarim, Edmon Kompilasi Hukum Telematika, PT. Raja Grafindo Perkasa, Jakarta 2003

Makarim, Edmon, Tanggung Jawab Hukum Penyelenggara Sistem Elektronik, Rajawali Pers, Jakarta, 2010 
Rosadi , Sinta Dewi, Perlindungan Privasi atas Informasi Pribadi dalam E-Commerce menurut Hukum Internasional, Widya Padjadjaran, Bandung, 2009.

Sanusi, M. Arsyad, Teknologi Informasi \& Hukum E-commerce, PT. Dian Ariesta, Jakarta, 2004

Alan Westin: Privacy is the claim of individuals, group or institution to determine for themselves when, how, and to what extent information about them is communicated to others dalam, Allan Westin, Alan F. Westin, Privacy and Freedom, London, 1967,

\section{Jurnal}

Mark F. Kightlinger, E. Jason Albert, and Daniel P. Cooper, Convention for the Protection of Individuals with Regard to Automatic Processing of Personal Data of 28 January 1981, dapat diakses http://conventions.coe.int/treaty/EN/Treaties/HTML/108.htm.

Samuel Warren \& Louis D. Brandeis, "The Right To Privacy", Harvard Law Review, Volume 4, 1890

\section{Publikasi Ilmiah}

Graham Greenleaf, 76 Global Data Protection Laws, Privacy Laws \& Business Special Report, September 2011.

Rencana Pembangunan Jangka Panjang Nasional 2005-2025

\section{Peraturan Perundang-Undangan}

Peraturan Pemerintah Nomor 82 Tahun 2012 tentang Penyelenggaraan Sistem dan Transaksi Elektronik, LNRI Tahun 2012 Nomor 189, TLNRI Nomor 5348

Uni Eropa (EU General Data Privacy Regulation)

Personal Data Protection Act 2010 Malaysia

Personal Data Protection Ordonance (PDPO) Hongkong

\section{Internet}

https://privacyinternational.org/, diakses pada tanggal 11 November 2018. Lihat juga Banisar, Privacy \& Human Rights, An International Survey of Privacy Laws and Developments, Electronic Privacy https://news.detik.com/berita/d-3158671/duh-sales-kartu-kredit-gadungan-inigunakan-uang-haram-buat-naik-haji http://aitinesia.com/3-contoh-pelanggaran-privasi-yang-terjadi-di-internet https://www.hukumonline.com/berita/baca/lt59cb4b3feba88/data-pribadi-dan-duadasar-legalitas-pemanfaatannya-oleh--daniar-supriyadi, Indonesia sangat memerlukan undang-undang perlindungan data pribadi, http://theconversation.com/indonesia-sangat-memerlukan-undang-undangperlindungan-data-pribadi-92607, diakses pada tanggal 14 November 2018 Pukul 19.22 WIB. 
SELISIK - Volume 6, Nomor 1, Juni 2020 ISSN:2460-4798 (Print) \& 2685-6816 (Online)

http://scdc.binus.ac.id/himslaw/2017/03/perlindungan-data-pribadi-berdasarkanhukum-positif-indonesia/ 